\title{
ANNA KOMNENE'S DESCRIPTION OF THE BATTLE OF DYRRACHIUM. SIMILARITIES WITH THE DESCRIPTIONS OF THE BATTLE OF HASTINGS TAKEN FROM ANGLO-NORMAN CHRONICLERS ${ }^{1}$
}

\author{
Theocharis Alexopoulos \\ National Kapodistrian University of Athens, Greece.
}

\begin{abstract}
The objective of this article is to highlight the striking similarities between the narratives of Anglo-Norman sources concerning the battle of Hastings (14 October of 1066), fought between the Normans of duke William of Normandy and the Anglo-Saxons of king Harold Godwinson and the narrative, respectively, of Anna Komnene for the battle of Dyrrachium (18 October of 1081), fought between the Normans of Robert Guiscard and the Byzantines of emperor Alexios I Komnenos. The author tries to support the theory that Anna Komnene made a deliberate attempt to incorporate in her narrative the central events and details of the battle of Hastings.
\end{abstract}

Keywords: battle of Hastings - Anna Komnene - battle of Dyrrachium - Robert Guiscard - Alexios I Komnenos.

\section{LA DESCRIPCIÓN DE ANNA COMNENO DE LA BATALLA DE DIRRAQUIO. SIMILITUDES CON LAS DESCRIPCIONES DE LA BATALLA DE HASTING TOMADAS DE LOS CRONISTAS ANGLO-NORMANDOS}

Resumen: El objetivo de este artículo es destacar las sorprendentes similitudes entre las narraciones de las fuentes anglo-normandas sobre la batalla de Hastings (14 de octubre de 1066), entre los normandos del duque Guillermo de Normandía y los anglosajones del rey Harold Godwinson, y la narración de Ana Comnena de la batalla de Durrachio (18 de octubre de 1081) entre los normandos de Robert Guiscard y los bizantinos del emperador Alexis I Comneno. El autor trata apoyar

1 This article constitutes a development of the writer's speech in the Postgraduate Colloquium of $26^{\text {th }}$ May 2012 of University of Birmingham (Middle Earth) with the title "The battle of Dyrrachium (1081)-Anna Komnene and her knowledge on the battle of Hastings (1066)". 
la teoría de que Ana Comnena hizo un intento deliberado de incorporar en su narrativa los eventos centrales y los detalles de la batalla de Hasting.

Palabras clave: Batalla de Hastings - Ana Comneno - Batalla de Dirraquio Roberto Guiscardo - Alexis I Comneno.

Recibido: 23.09.2019 - Aceptado: 23.04.2020

\section{Correspondencia: Theocharis Alexopoulos \\ Email: theocharis_alex@yahoo.gr \\ Byzantine history Phd holder.}

here is hardly a field of historical knowledge and historical
speculation concerning Hastings that is still uncovered. The
consequences of William the Conqueror's most resounding victory have been extensively studied by modern researchers, although debates and minor disagreements between them regarding certain details of the battle and the way it was fought are still encountered. The battle itself was established as a legendary event throughout the Western Europe. But, can traces of this very important event be found also in the narratives, histories and tales of more distant people such as the Byzantines? The answer perhaps lies in the details of Anna Komnene's account on the battle of Dyrrachium as described in her Alexiad.

The objective of this study is to highlight the striking similarities between the narratives of Anglo-Norman sources concerning the battle of Hastings (having taken place in $14^{\text {th }}$ October of 1066, and fought between the Normans of duke William of Normandy and the Anglo-Saxons of king Harold Godwinson) and the narrative, respectively, of Anna Komnene for the battle of Dyrrachium (having taken place in $18^{\text {th }}$ October of 1081, and fought between the Normans of Robert Guiscard and the Byzantines of emperor Alexios I Komnenos). Understandably, only some of the major and more detailed sources which are safely dated prior and during the span of life of Anna Komnene (1083 - approximately 1150), namely William 
of Poitiers ${ }^{2}$, William of Jumièges ${ }^{3}$, the Carmen de Hastingae Proelio ${ }^{4}$ and Ordericus Vitalis ${ }^{5}$, will be used in this venture. Of all these 4 sources, of primary importance is the work of William of Poitiers, which contains the greatest wealth of information concerning the battle of Hastings, although it gives the story from the Norman point of view.

As it is anticipated, many modern scholars such as Sir Charles Oman $^{6}$ and recently others such as J. Haldon ${ }^{7}$, J. Birkenmeier ${ }^{8}$ and G. Theotokis ${ }^{9}$ have demonstrated the similarities between Hastings and Dyrrachium. But can we assume that these similarities are not just a mere repetition of the same battle tactics on behalf of the Normans nor a product

2 Gesta Guillelmi ducis Normannorum et Regis Anglorum.

3 Gesta Normannorum Ducum.

4 Carmen de Hastingae Proelio. On the long academic debate regarding the issue of the worthlessness or not of the Carmen as a source for the battle of Hastings see, Davis, R. H. C., (1978), "The Carmen de Hastingae Proelio", English Historical Review 93, pp. 241-261. Also see, Davis, R. H. C., - Engels, L. J., (1979), "The Carmen de Hastingae Proelio: A Discussion", Proceedings of the Battle Conference on Anglo-Norman Studies 2, pp. 1-20 and Brown, R. A., (1981), "The Battle of Hastings", Proceedings of the Battle Conference on Anglo-Norman Studies 3, pp. 2-3. Also see, Morillo, S., (1996), The Battle of Hastings: Sources and interpretations, Woodbridge, p. 45 and Barlow, F., (2001), The Godwins: The Rise and Fall of a Noble Dynasty, London, p. 10.

$5 \quad H i s t o r i a$ Ecclesiastica. Books III through VI form the original nucleus of the work (a history of St Evroul). Planned before 1122, they were mainly composed in the years 1123-1131. The fourth and fifth books contain long digressions on the deeds of William the Conqueror in Normandy and England. Before 1067 these are of little value, being chiefly derived from the two aforementioned sources: William of Jumieges and William of Poitiers. pp. 26-27.

(1885), The art of the war in the Middle Ages, A.D. 378-1515, Oxford, Tempus.

(2001), The Byzantine wars: battles and campaigns of the Byzantine eral,

(2002), The development of the Komnenian Army: 1081-1180, Leiden.

9

(2010), The campaigns of the Norman dukes of southern Italy against Byzantium, in the years between 1071 and 1108 AD, $\mathrm{PhD}$ thesis, University of Glasgow. 
of a parallel military evolution development which occurred in two remote areas (namely Normandy, south Italy and the Balkans), but a deliberate attempt of Anna Komnene to incorporate in her narrative the central events and details of the battle of Hastings which she had been informed of, either through the aforementioned works, eyewitnesses who participated in the battle and then traveled south to serve in the Byzantine army, or finally through their descendants who also fled to Byzantium and served in the elite imperial regiments such as the renowned Varangian guard ${ }^{10}$. To prove such hypothesis would be of course a difficult and challenging but not entirely impossible task.

First of all, let us begin with a general analysis of the major events of the battle of Hastings as they have come down to us through the written sources of the late $11^{\text {th }}$ and early $12^{\text {th }}$ century. The basis for this analysis provides mainly the work of William of Poitiers, the Gesta Guillelmi II ducis Normannorum et Regis Anglorum, because of the large amount of information provided to the reader. Of course, this work expresses certain pro-Norman bias. Therefore we should handle the information from this source carefully. But this does not alter the fact that this source is the most valuable, the most well-informed and the most exact among all other sources concerning the battle, plus the fact that it is written by an experienced soldier's eye of view ${ }^{11}$.

As it is nowadays widely accepted, the battle of Hastings was fought at the early hours of 14 October 1066 on a hill, probably Senlac (or Santlache) Hill, about 5 to 8 miles northwest of Hastings close to the present-day town of Battle, in East Sussex county ${ }^{12}$. If we attempt a reconstruction of the main events of the battle, the course of action

10 For a general study of the history of the Varangian guard, see Blondal, S., (1978), The Varangians of Byzantium. Translated, revised and rewritten by Benedikt S. Benedikz, Cambridge.

11 William of Poitiers, Gesta Guillelmi ducis Normannorum et Regis Anglorum, ed. and trans. by R. H. Davis and M. Chibnall, Oxford 1998, intr., p. xxxv.

12 Horsfield, T. W., (1834), The History, Antiquities and Topography of the County of Sussex, 2 vols, Bakewell. Also see, Short, B., - Leslie, K., (1999), eds, Historical Atlas of Sussex, Phillimore. 
would be like this ${ }^{13}$ : according to William of Poitiers, duke William after securing his army and fleet by erecting two forts, one each in Pevensey and Hastings, conducted continuous reconnaissance operations in the nearby area, in some of which he might have participated himself ${ }^{14}$. According to the same writer and the writer of the Carmen, King Harold attempted to surprise the Normans with a night attack ${ }^{15}$. Whatever the reason, his plan failed ${ }^{16}$ as the Normans gained early warning through their mounted scouts ${ }^{17}$, so he hastily deployed his army on Senlac ridge. The Normans were initially deployed on a ridge approximately one mile from Harold's position, called Telham Hill. According to William of Poitiers and the Carmen, the Anglo-Saxons dismounted and formed a dense infantry phalanx (with interlocking shields), the traditional shield wall ${ }^{18}$. According to these two sources and William of Jumièges, Duke William deployed his army in three lines of battle, consisting of the archers and the crossbowman at the front, the heavy infantry wearing mailed hauberks at the second and the mounted knights, the Norman weapon par excellence, at the third ${ }^{19}$.

13 Thoroughly detailed reconstructions of the major events of the battle have been attempted by many renowned scholars. The bibliography of secondary sources generated by Hastings is endless. Suffice to say that the aim here is to highlight the events which are similar to those found in the narrative of Anna Komnene.

14 Gesta Guillelmi, II.9

15 Gesta Guillelmi, II.14. Guy Bishop of Amiens, Carmen de Hastingae Proelio, ed. and trans. C. Morton and H. Muntz, Oxford 1972, vv. 280-282, 317.

16 The Anglo-Saxon chronicle provides a diametrically opposed point of view, by suggesting that it was William the one who surprised Harold and that the latter was forced to fight with only the two thirds of his army deployed. See also, Florence of Worcester, Chronicon ex Chronicis, transl. T. Forester, London 1854 , A.D. 1066, p. 170 (this work is also known as the chronicle of John of Worcester which according to his own remark continued and finished the section of the chronicle events after 1118. However, the prevalent view today is that John of Worcester was the principal author and compiler of the chronicle).

17 Gesta Guillelmi, II.14.

18 Gesta Guillelmi, II.16. Carmen de Hastingae Proelio, vv. 365-367, 373377. 
The Carmen provides the interesting information that the left flank of the Norman army comprised of French contingents, the right of Bretons and the Duke himself occupied the centre with his Norman knights ${ }^{20}$. William of Poitiers claims that the Bretons were on the left (perhaps we have here a case of opposite point of view of the same battle line? $)^{21}$.

The battle opened with the advance of the Normans ${ }^{22}$ and it seems that their archers shot several volleys but many of their arrows hit the shield wall and had very limited effect ${ }^{23}$. Then their heavy infantry charged up the hill, but failed to make an impression on the English battle line while the English answered with a rain of stones, javelins and other improvised short and medium ranged weapons ${ }^{24}$. When the assault of the Norman heavy cavalry also faltered, then the left flank, comprising the Bretons, gave way and fled. They were followed by the rest of the army because of a false rumour that Duke William was dead ${ }^{25}$. Unable to resist the temptation, many of the Anglo-Saxons broke ranks and pursued the Normans. It was only with great difficulty and after throwing off his helmet in order to get recognized by his men that William was able to rally his fleeing troops ${ }^{26}$. Then William and a group of his knights successfully counter-attacked the pursuing English, who were no longer protected by the shield wall, and cut down large numbers of them. According to William of Poitiers, whom Orderic in his narrative for the battle quotes nearly verbatim, the Normans upon seeing the success of their counter-attack after their initial rout feigned twice more flight and drew the English into pursuing them

Gesta Normannorum Ducum of William of Jumièges, Orderic Vitalis and Robert of Torigni, ed. and transl. by E. Van Houts, vol.2, Books V-VIII, Oxford 1995, VII.36.

20 Carmen de Hastingae Proelio, vv. 413-414.

21 Gesta Guillelmi, II.17.

22 See also the much latter (approximately 1136-1137) chronicle of Geoffrey Gaimar, L Estoire des Engles, ed. A. Bell, Oxford 1960, v.5307.

23 Gesta Guillelmi, II.17. Carmen de Hastingae Proelio, vv. 379-382.

24 Gesta Guillelmi, II.17.

25 Gesta Guillelmi, II.17. Carmen de Hastingae Proelio, vv. 429-432.

26 Gesta Guillelmi, II.18. Carmen de Hastingae Proelio, vv. 445-459. 
with devastating effect ${ }^{27}$. (Perhaps this was the turning point of the battle).

The rest of the story, the death of King Harold and his brothers and the ultimate defeat of the English army is well known. We will only focus on the events that bear similarity with the narrative of Anna Komnenes' description of the battle of Dyrrachium. The battle of Dyrrachium ${ }^{28}$, was fought between the Normans and the Byzantines (at 18 ${ }^{\text {th }}$ October 1081) when the later under the leadership of Alexios I Komnenos tried to relieve the besieged city from the Norman blockade. Of special interest is the participation, the heroic fight and the subsequent annihilation of the Byzantine elite unit known as the Varangian Guard which was then, as it is nowadays commonly accepted, mostly comprised by Anglo-Saxon warriors $^{29}$.

27 Gesta Guillelmi, II.20-21. On the contrary the author of the Carmen although in generally in agreement with the Gesta at least for the first part of the battle suggests that there was only one feigned flight which turned to a real one and only the timely intervention of William save the day for the Normans (vv. $423-424,433-438,461)$. On the debate about the veracity or not of the famous feigned flight ruse, see Brown, 1980, pp.1-21; Bachrach, B. S., (1971), The Feigned Retreat at Hastings, Medieval Studies 33, pp. 344-347; Theotokis, 2010, pp. 222-223.

28 Brown, R. A., (1984), The Normans, Woodridge, p. 118. Birkenmeier, 2002, pp. 62-66; Haldon, 2001, pp. 133-137; Theotokis, 2010, pp. 208-230.

29 See for example, Vasiliev, A. A., (1937), "The Opening Stages of the Anglo Saxon Immigration to Byzantium in the Eleventh Century," Seminarium Kondakovianum 9, pp. 39-70, Shepard, J., (1973), "The English and Byzantium: A Study of Their Role in the Byzantine Army in the Later Eleventh Century," Traditio 29, pp. 53-92, Ciggaar, K., (1974), "L'emigration anglaise a Byzance apres 1066," Revue des etudes Byzantines 32, pp. 301-342. Idem, (1981), "England and Byzantium on the Eve of the Norman Conquest," Anglo-Norman Studies. Proceedings of the Fifth Battle Abbey Conference 5, pp. 78-96, Godfrey, J., (1978), "The Defeated Anglo-Saxons Take Service with the Eastern Emperor," Anglo-Norman Studies. Proceedings of the First Battle Abbey Conference 1, pp. 63-74, Head, C., (1977), "Alexios Comnenos and the English," Byzantion 47, pp. 186-198, Fell, C., (1974), "The Icelandic Saga of Edward the Confessor: Its Version of the Anglo-Saxon Emigration to Byzantium," Anglo-Saxon England 3, pp. 179-196, Pappas, N., (retrieved 2-122019), English Refugees in the Byzantine Armed Forces: The Varangian Guard and Anglo-Saxon Ethnic Consciousness, De Re Militari: The Society for 
Here follows a brief description of the battle with emphasis being given mostly to the similarities found in the narrative of Anna Komnene and the major sources of the battle of Hastings. According to Anna, at the beginning of October of 1081 the Norman duke Robert Guiscard found himself in a perilous situation resembling the situation of Duke William fifteen years ago $^{30}$. The Byzantine army was approaching, the siege of the city had turned into a stalemate and the Venetian fleet threatened to cut off the Norman supply route and the only way of escape available ${ }^{31}$. According to Anna, Alexios and Robert exchanged embassies in which the latter formulated his indirect claims to the Byzantine throne by taking up the cause of the deposed emperor Michael VII Doukas (by Nicephorus Votaniates in 1078) ${ }^{32}$. This was a situation pretty much reminiscent of that described by the Carmen with the exchange of embassies between king Harold and duke William ${ }^{33}$ before the battle of Hastings. When these negotiations failed, Alexios tried, unsuccessfully, to surprise his foe with a night attack ${ }^{34}$. In the early morning of October $18^{\text {th }} 1081$ the two opposing armies deployed their battle lines near the city with their respective flanks beside the seashore. Alexios placed his Varangians with archer support in front of his battle line, so as to negate the impact of the charge of the much feared Norman cavalry upon his main line. It is interesting to note that these troops which were mostly comprised of Anglo-Saxons ${ }^{35}$, arrived at

Medieval Military History and Faundez Rojaz, G. A., (2012), "The English Exodus to Ionia": The Identity of the Anglo-Saxon Varangians in the Service of Alexios Comnenos I (1081-1118), Master's Thesis, Marymount University.

$30 \quad$ Gesta Guillelmi, II.15.

31 Annae Comnenae, Alexias, ed. D. R. Reinsch - A. Kambylis, (CFHB 40.1), Berlin 2001, IV.3.2-3.

32 Ibid., IV.5.1-4.

33 Carmen de Hastingae Proelio, vv.195-306.

34 Alexias, IV.6.1.

35 Ibid., IV.6.2 ("the ones which carry on their shoulders the two edged swords"). She also calls them "the axe-bearing barbarians from Thule" (Alexias, II.9.4). Geoffrey Malaterra, De Rebus Gestis Rogerii Calabriae et Siciliae Comitis et Roberti Guiscardi Ducis fratris eius, ed. Ernesto Pontieri [Rerum Italicarum Scriptores V pt.1], Bologna, 1927-8, III.27, and Ordericus Vitalis, Historia Ecclesiastica, english trans., M. Chibnall, The Ecclesiastical History of 
the battlefield mounted but then dismounted and formed a shield wall ${ }^{36}$, just like at Hastings. Also, Alexios seems to have deployed his army on a

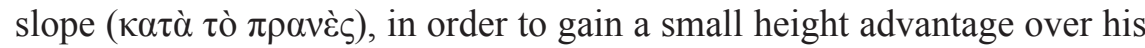
enemies ${ }^{37}$. Robert Guiscard formed his battle line, with his two flanks under

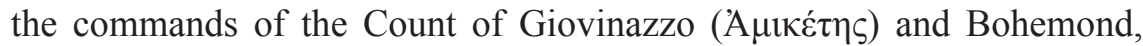
Guiscard's son, respectively, while Guiscard himself was facing Alexios at the centre ${ }^{38}$.

According to Anna, the battle began with some minor skirmishing actions and the slowly advance of the Norman army towards the Byzantine positions $^{39}$. The Normans under the command of Count of Giovinazzo (probably on the right flank) charged the Varangian flank but the Varangians stood their ground and the Normans started a retreat which turned to a rout towards the beach ${ }^{40}$. This flight which threatened to disintegrate the whole Norman battleline, was stopped, as Anna informs us, by the timely intervention of Guiscard's wife Sigelgaita ( $\Gamma \alpha$ ó $\tau \alpha)$ which rallied the fleeing troops, spear at hand, as William had done at Hastings ${ }^{41}$. The Normans then turned against the pursuing Englishmen (perhaps another case of the feigned flight manoeuvre) which were already exhausted by their heavy armour and inflicted on them heavy casualties. The few remaining Varangians fled into the church of the Archangel Michael. The Normans immediately set the church on fire, and all the Varangians perished ${ }^{42}$. After the destruction

Orderic Vitalis, 6 vols [Oxford Medieval Texts], Oxford 1968-1980, IV. 2.172 and VII.3.169. Both agree that Alexios used English troops in his battles against Robert Guiscard.

36 Alexias, IV.6.2. Their numbers though were smaller. Modern researchers calculate their numbers as between 1400 and 2000 men (see, Haldon 2001, p.134).

37 Ibid., IV.6.2.

38 Ibid., IV.6.1. It is not clear if Bohemond was on the left or on the right flank. Most probably he was on the left and Amicetes commanded the right.

39 Ibid., IV.6.4. See also, Malaterra, De Rebus Gestis Rogerii, III.27.

$40 \quad$ Alexias., IV.6.4.

41 Ibid., IV.6.5. Cf., Gesta Guillelmi, II.18. For Sigelgaita see, Scozza, M., (1994), Sichelgaita, Signora del Mezzogiorno. ed. Alfredo Guida, Naples. Alexias, IV.6.6. 
of the English elite corps, Guiscard turned the tables on Alexios and just as William had done at Hastings ${ }^{43}$ attacked personally the Byzantines which started to falter and eventually collapsed. Alexios' rearguard action and personal bravery (he fought with three Norman knights) ${ }^{44}$, didn't alter the outcome of battle: a major tactical Norman victory.

It becomes evident that Anna's account of the battle of Dyrrachium bears many similarities to major events of the battle of Hastings. Could it be a mere coincidence? According to Anna, Robert Guiscard attacked the Byzantines first. But another source for the battle of Dyrrachium, although pro-Norman, William of Apulia, claims that it was the Byzantines who attacked first and turned the allies of the Normans to flight (namely the Calabrians and the Lombards) $)^{45}$. Another pro-Norman source, Geoffrey Malaterra also states that it was the English who charged first at the Normans ${ }^{46}$. Then comes a number of quite familiar scenes: the attempted surprise night attack of Alexios, the Byzantine army's deployment on a slope, the Norman attack on the flank that failed against the English resistance, the Norman rout and the following disorderly English pursue (they abandoned the shield wall thus making themselves vulnerable to a counter attack), the defeat of the Varangians and the decisive final attack of Guiscard against the byzantine main line. But there is also one more scene requiring our attention. That is the role played by Sigelgaita. William of Apulia says that she was injured by a chance arrow but nowhere states that it was she who rallied the Norman troops in the spectacular way mentioned above $^{47}$. A display of prowess like this could have hardly gone unnoticed by Norman panegyrists.

A closer look should also be given at an incident that usually goes unnoticed. Anna reports that immediately prior the battle of Dyrrachium,

Ibid., IV.6.7. Cf., Gesta Guillelmi, II.22-24.

44 Compare this description of Anna Komnene with the scene in Carmen of the four knights attacking king Harold (vv.532-550).

45 Guillelmus Apuliensis, Gesta Roberti Wiscardi, ed. M. Mathieu, Palermo 1961, IV.224.

46 Malaterra, De Rebus Gestis Rogerii, III.27. Malaterra states that the English requested the emperor to form the vanguard because they enjoyed fighting in the forefront. 
Guiscard performed a speech in order to inspire and raise the morale of his troops. According to Anna, he decided to burn his baggage and make holes to his ships so as they would sink once on the open sea ${ }^{48}$. That way his men would have no other alternative than to fight to the last man. A similar thing happens when Anna comes down to the details of the much latter invasion of the Albanian coast (1107-1108), performed and executed by Guiscard's son, Bohemond. The Norman leader reportedly burned his fleet once he finished his disembarkation nearby Dyrrachium ${ }^{49}$. Those two incidents clearly constituted a "topos", as it would be far too risky for an invader on a foreign and hostile land to disrupt his own supply route and the only way of escape available ${ }^{50}$.

No early source on the Hastings campaign reports anything similar when dealing with Duke William early actions prior the battle. But it is astonishing that two latter sources, namely the Roman de Rou written by Master Wace and the Chronicle of the Battle Abbey, both dated after the middle of 12th century, make reference to respective actions of William the conqueror. According to the first, William had the fleet disabled so as to motivate his troops to fight as hard as they could ${ }^{51}$, while according to the Chronicle of the Battle Abbey, William burned his ships for the same reasons ${ }^{52}$. The problem is that Alexiad preceded those two sources by at least two or three decades, even more, so it is quite improbable that they were used by Anna as her sources ${ }^{53}$. Perhaps a tradition like this made

$48 \quad$ Alexias, IV.5.7.

49 Ibid., XIII.2.2.

50 Similar "topoi" consisting the burning or the dismantling of fleets that carry invasion forces, are to be found in other medieval sources.

51 The Bayeux tapestry is considered to contradict Wace's supposed story of the ships being destroyed. Probably they were dismantled and stored in the coastal forts. M. Wace, Roman de Rou, english trans. E. Taylor, London 1837, XII.

52 From such dismantling may have arise the report of destruction, which the chronicle of Battle Abbey improves into actual burning (The Chronicle of Battle Abbey, 1066-1176, ed. M. A. Lower, London 1851, p. 3)

53 From the Italian Norman sources only Malaterra reports that Guiscard burned his fleet in order to motivate his troops to fight harder (De Rebus Gestis Rogerii, III.27. Anna, though, clearly states that the ships were rendered unusable 
her way to Byzantium through eye-witnesses or their descendants who transmitted this kind of information to Anna and she used it accordingly. If this is the case, then we have here a strong evidence that Anna used no written sources but indeed orally transmitted testimonies from AngloSaxon warriors who served at the Byzantine army ${ }^{54}$. In any case she seems quite well informed about the events that occurred in distant England.

As it becomes quite clear from the abovementioned, Anna's description of the battle of Dyrrachium is quite reminiscent of Hastings. A mini-Hastings, at least at the opening stages of the battle, would be, perhaps, a better term. Anna, like most medieval authors, had a tendency throughout her whole work to use interpolations from earlier writers (classical and medieval). Such sources can hardly be detected in Anna's work, since she had a talent to integrate them perfectly in her narratives ${ }^{55}$. There is no intention to degrade the historical value of Anna Komnene's narrative of the battle of Dyrrachium. Her trustworthiness on major events has long been established. In general, the events went the way she describes. But we cannot be certain about the minor details of the battle. That is why a comparison with the respective narratives of William of Apulia and Geoffrey Malaterra is necessary and helpful.

The details of Anna's narrative indicate that she clearly had a general knowledge about the events that took place in the far England in 1066 and that she used that knowledge as means to enrich her narrative. It is also

rather than burned). William of Apulia remains silent about this incident, a fact that raises questions about how much it corresponds to reality. Perhaps Anna Komnene and Malaterra had access to a common source? Or it was that she had access to a translated version of Malaterra work? (translated for her by court officials and translators or by Bryennios himself. After all she used the scene of the burning of the ships to describe the Bohemond's latter invasion).

54 Anna names twice a source of her own, a Latin emissary of the bishop of Bari who had access to Guiscard's camp and provided her with information (Alexias, III.12.8 and IV.5.1). She also states that she used information from old soldiers (although she does not mention their origin), some of which also wrote down their memories but clearly they were not talented enough to make their names known as historians and ended their lives as monks (Alexias, XIV.7.7). Could some or any of these have had originated from England?

55 Besides the role played by the English at Hastings and at Dyrrachium is hardly the same. The similarities though are quite impressive. 
quite possible that she viewed her father as the byzantine equivalent of Harold Godwinson. After all they were both fighting in defence of their homeland. They both faced Norman invasion as soon as they ascended their thrones. They were both considered usurpers by their enemies and had to fight off multi-fronted invasions against different enemies. And they both fought and lost decisive battles against the Normans. The main difference is that Alexios survived the Norman hostility, whereas Harold lost his life and his realm ${ }^{56}$.

From what has been said arises the reasonable conclusion, as expressed by Jonathan Shepard and other scholars, that Byzantines and Anglo-Saxons had close relations during the reigns of the Komnenian emperors. It is quite possible that the Komneni showed much sympathy for them, never shown before to other western Europeans because their misadventure reminded to them familiar misfortunes (oikєĩ $\alpha \alpha \kappa \alpha$ ) of the wars against the Normans of Sicily. The excessive eagerness shown by the English Varangians at Dyrrachium (to join battle with the Normans) expressed in a point their desire to avenge Hastings.

A handful of questions arise: first of all, by which means and through whom had Anna Komnene access to Anglo - Norman literature about Hastings (mainly William of Poitiers and the Carmen). Did she had any acquaintance with Latin? Could she read and understand latin in such a degree as to integrate to her narrative work information from works originally written in latin or did she made good use of the imperial translation department?

It is almost certain that she didn't understand any latin. But somehow she managed to have access to latin texts, in a translated form. William of Poitiers was not quite popular in Norman England ${ }^{57}$. Perhaps Anna was able to access his work indirectly through the more famous work of Orderic Vitalis who quotes lengthy passages from the work of William.

$56 \quad$ The difference being made by the fact that Harold fought on foot, while Alexios was mounted, a fact that prevent him being captured or even being killed.

57 With no known copied manuscripts produced, this has led to some scholars theorizing that William ended his days in political disgrace. See, Davis, R.H.C., (1981), 'William of Poitiers and his history of William the Conqueror', in: Davis, R.H.C. and Wallace-Hadrill, J.M. (eds.), The Writing of history in the Middle Ages: essays presented to Richard William Southern, Oxford, p.92. 
On the other hand an access to a manuscript of the Carmen seems quite improbable.

Secondly, the reason why she doesn't even makes the slightest mention about her sources. One reason might be probably because it is quite plausible that she never used any written sources for the description of the battle of Dyrrachium, but instead she based her description on eyewitness testimony (survivors of the battle of Hastings or their descendants serving in the Byzantine army $)^{58}$. If, though, we accept that she did used written works as her sources, then we can conclude that she doesn't mention them because firstly, she never gives any information about her sources anyway and secondly, because these distant works are mainly pro-Norman, indifferent towards Byzantium and contain anti-byzantine bias ${ }^{59}$.

The last question remaining to be answered is, in case that Anna had knowledge of the Gesta (either through a copy of the original or through the work of Orderic) or the Carmen, by which means she could have gained access to these works and by which way they could have arrived to Constantinople. Perhaps these works came to Constantinople through Byzantine envoys and recruiting missions that had been sent to England. There is ample evidence of such missions having been undertaken during the lifetimes of Alexios, his son Ioannes and his grandson Manuel ${ }^{60}$. But this is another story to be told.

Also the way the English Varangians met their deaths needs further research. According to Malaterra ${ }^{61}$, the Varangians found refugee to the church of St. Nicholas but because there was no room for all of them inside many clambered onto the roof which then collapsed killing those on top and

$58 \quad$ See above, footnote 53 .

59 William of Poitiers calls the German empire, Roman Empire, something totally unaccepted for the Byzantines and their imperial political theory (that is, there was only one and true Roman empire and this had as its capital the imperial city of Constantinople).

60 Head 1977, p. 194 (case of Ulric). From all the Byzantine emperors predating him, Alexios alone appeared as the most famous patron of the English (p. 193). See also, Ciggaar 1981, p.86 (case of Raphael protospatharios), Nicol, D. M., (1974), Byzantium and England, Balkan Studies 15, pp. 179-203, here p.183, 192-3 (the chronicle of Abingdon tells about the embassy sent by Alexios to Henry I some time between 1100-1118 mentioning a certain Ulfric). 
inside alike ${ }^{62}$. Anna's description of the Normans setting fire to the church in which the surviving Varangians had found shelter bears resemblance to a story narrated by a much earlier writer and his famous description of the battle of Hadrianople at 378 A.D.; Ammianus Marcellinus ${ }^{63}$. One of Ammianus' versions of the death of Valens contains the information that ultimately the emperor met his fate inside a church, when the Goths set fire to it just like the Anglo-Saxons of Anna's description.

In conclusion, Anna's description of the battle shows that she and her advisors in military subjects ${ }^{64}$ had a very good understanding and knowledge of the ways and methods the british troops were fighting with. Whether Alexios indeed deployed his troops in this particular fashion because as a great tactitian and strategist had knowledge of the particular way and style of fighting of the Anglo-Saxon troops or Anna Komnene described the battle of Dyrrachium in such a way as to fit in her narrative perfectly the description of another battle by incorporating in it material from latin sources, is something that cannot be answered with any certainty. The many similarities between the general information deriving from the most important, early sources for the battle of Hastings and Alexiad, suggest that such a thing was feasible and not entirely out of question. If this is the case, and Anna quoted parts from Anglo-Saxon and Norman sources from distant England, it is indeed curious and odd enough why the same thing didn't happened with latin sources geographically closer to Byzantium, such as the works of the chroniclers of the Norman county of Sicily ${ }^{65}$.

62 There is of course a possibility for the Varangians to have found shelter in two different churches.

63 Ammiani Marcellini, Rerum Gestarum libri qui supersunt, ed. C. U. Clark, 2vols, Berlin 1910-1915, XXXI.13.14-16. It is, however, very difficult to support the hypothesis that Anna had access to the work of Ammianus.

64 Bryennios, her husband, must have had pivotal role on developing most of the battle scenes of the Alexiad.

65 E.g., the work of Geoffrey Malaterra. William's of Apulia work is peculiar as there are connections between it and the Alexias. See, Brown, P., (2011), 'The Gesta Roberti Wiscardi: A 'Byzantine' history?', Journal of Medieval History, 37:2, pp. 162-179 and Frankopan, P., (2013), 'Turning Latin into Greek: Anna Komnene and the Gesta Roberti Wiscardi', Journal of Medieval History, 39:1, pp. 80-99. 
We should keep in mind, however, that the Byzantines were in constant conflict with the Normans of Sicily during the reigns of all the Komneni ${ }^{66}$. Therefore, any access to literary sources from this area was probably very difficult, almost impossible. The direct diplomatic activity between the two states, especially during the reign of Alexios, was probably quite limited, restricted to a few formal delegations sent from and to either side $^{67}$.

Furthermore, due to the hostile intentions of the Normans of Sicily and south Italy, the main recruiting areas for foreign troops to serve in the byzantine army during the reign of Alexios Komnenos were the Scandinavian lands, Russia and England and not Italy anymore. There was a notable increase to the numbers of Anglo-Saxon warriors in service and a subsequent reduction of the number of Normans. By contrast, during the period immediately prior the ascendance of Alexios to imperial power, during the reign of Nicephoros Votaniates (1078-1081), Norman troops from Italy served in the byzantine army in numbers. It would have been easier for byzantine recruiting agents to bring back with them recruits, texts (containing historical as much as theological material) and information from England, than for byzantine ambassadors to do the same in Southern Italy.

We should also keep in mind that due to the hostile attitude of Malaterra and to a lesser degree of William of Apulia towards Byzantium, Anna would have been extremely hesitant to use material from their works, even if they were familiar to her. On the contrary, the more mild and indifferent disposal of the Anglo-Norman writers towards the Byzantines, with some minor exceptions, regarding the political status and supremacy of both the Byzantine and German empires, meant that she could use more

66 Excluding the notable exception of the reign of John II (1118-1143), the enmity between the two powers was renewed during the reigns of Manuel II Komnenos (1143-1180) and Roger II (1130-1154) and later on during the reigns of William II (1166-1189), Andronikos I Komnenos (1183-1185) and Isaac Angelos (1185-1195).

67 Although Alexios, during and immediately after the Dyrrachium campaign, seems that had no difficulty at all to contact notable Norman officials and come to terms with them, spreading in this way discontent among the Norman army ranks (Alexias, V.7.4). For diplomatic activity between Robert Guiscard and the Byzantines see, Alexias, I.15.2. 
handedly material from these sources.

In the absence of further evidence and research, the bold suggestion about Anna's integration of the battle of Hastings' narratives in her description of the battle of Dyrrachium has to remain a hypothesis.

\section{BIBLIOGRAPHICAL REFERENCES}

\section{Primary sources}

AMMIANI MARCELLINI, Rerum Gestarum libri qui supersunt, ed. C. U. Clark, 2vols, Berlin 1910-1915.

ANNAE COMNENAE, Alexias, ed. D. R. Reinsch - A. Kambylis, (CFHB 40.1), Berlin 2001.

FLORENCE OF WORCESTER, Chronicon ex Chronicis, transl. T. Forester, London 1854.

GEOFFREY GAIMAR, L Estoire des Engles, ed. A. Bell, Oxford 1960.

GEOFFREY MALATERRA, De Rebus Gestis Rogerii Calabriae et Siciliae Comitis et Roberti Guiscardi Ducis fratris eius, ed. Ernesto Pontieri [Rerum Italicarum Scriptores V pt.1], Bologna, 1927-8.

GUILLELMUS APULIENSIS, Gesta Roberti Wiscardi, ed. M. Mathieu, Palermo 1961.

GUY BISHOP OF AMIENS, Carmen de Hastingae Proelio, ed. and trans. C. Morton and H. Muntz, Oxford 1972.

ORDERICUS VITALIS, Historia Ecclesiastica, english trans., M. Chibnall, The Ecclesiastical History of Orderic Vitalis, 6 vols [Oxford Medieval Texts], Oxford 1968-1980.

THE CHRONICLE OF BATTLE ABBEY, 1066-1176, ed. M. A. Lower, London 1851.

M. WACE, Roman de Rou, ed. and english trans. E. Taylor, London 1837.

WILLIAM OF JUMIEGES, ORDERIC VITALIS AND ROBERT OF TORIGNI, Gesta Normannorum Ducum, , ed. and transl. by E. Van Houts, vol.2, Books V-VIII, Oxford 1995.

WILLIAM OF POITIERS, Gesta Guillelmi ducis Normannorum et Regis Anglorum, ed. and trans. by R. H. Davis and M. Chibnall, Oxford 1998. 


\section{Secondary literature}

BACHRACH, B. S., (1971), “The Feigned Retreat at Hastings”, Medieval Studies $33,344-347$.

BARLOW, F., (2001), The Godwins: The Rise and Fall of a Noble Dynasty, London.

BIRKENMEIER, J., (2002), The development of the Komnenian Army: 10811180, Leiden.

BLONDAL, S., (1978), The Varangians of Byzantium. Translated, revised and rewritten by Benedikt S. Benedikz, Cambridge.

BROWN, P., (2011), 'The Gesta Roberti Wiscardi: A 'Byzantine' history?', Journal of Medieval History, 37:2, 162-179.

BROWN, R. A., (1981), "The Battle of Hastings", Proceedings of the Battle Conference on Anglo-Norman Studies 3, 1-21.

BROWN, R. A., (1984), The Normans, Woodridge.

CIGGAAR, K., (1974), "L'emigration anglaise à Byzance après 1066," Revue des etudes Byzantines 32, 301-342.

CIGGAAR, K., (1981), "England and Byzantium on the Eve of the Norman Conquest," Anglo-Norman Studies. Proceedings of the Fifth Battle Abbey Conference 5, 78-96.

DAVIS, R. H. C., (1978), “The Carmen de Hastingae Proelio”, English Historical Review 93, 241-261.

DAVIS, R. H. C., - ENGELS, L. J., (1979), "The Carmen de Hastingae Proelio: A Discussion", Proceedings of the Battle Conference on Anglo-Norman Studies 2, 1-20.

DAVIS, R.H.C., (1981), 'William of Poitiers and his history of William the Conqueror', in: Davis, R.H.C. and Wallace-Hadrill, J.M. (eds.) The Writing of history in the Middle Ages: essays presented to Richard William Southern, Oxford, 70-100.

FAUNDEZ ROJAZ, G. A., (2012), "The English Exodus to Ionia”: The Identity of the Anglo-Saxon Varangians in the Service of Alexios Comnenos I (10811118), Master Thesis, Marymount University.

FELL, C., (1974), "The Icelandic Saga of Edward the Confessor: Its Version of the Anglo-Saxon Emigration to Byzantium," Anglo-Saxon England 3, 179-196.

FRANCOPAN, P., (2013), 'Turning Latin into Greek: Anna Komnene and the Gesta Roberti Wiscardi', Journal of Medieval History, 39:1, 80-99.

GODFREY, J., (1978), “The Defeated Anglo-Saxons Take Service with the Eastern Emperor," Anglo-Norman Studies. Proceedings of the First Battle Abbey Conference 1, 63-74.

HALDON, J., (2001), The Byzantine wars: battles and campaigns of the Byzantine era, Tempus. 
HEAD, C., (1977), “Alexios Comnenos and the English,” Byzantion 47, 186-198.

HORSFIELD, T. W., (1834), The History, Antiquities and Topography of the County of Sussex, 2 vols, Bakewell.

NICOL, D. M., (1974), Byzantium and England, Balkan Studies 15, 179 203.

OMAN, sir CHARLES, (1885), The art of the war in the Middle Ages, A.D. 3781515, Oxford.

MORILlO, S., (1996), The Battle of Hastings: Sources and interpretations, Woodbridge.

PAPPAS, N., (retrieved 2-12-2019), English Refugees in the Byzantine Armed Forces: The Varangian Guard and Anglo-Saxon Ethnic Consciousness, De Re Militari: The Society for Medieval Military History.

SCOZZA, M., (1994), Sichelgaita, Signora del Mezzogiorno. ed. Alfredo Guida, Naples.

SHEPARD, J., (1973), "The English and Byzantium: A Study of Their Role in the Byzantine Army in the Later Eleventh Century," Traditio 29, 53-92.

SHORT, B., - LESLIE, K., (1999), eds, Historical Atlas of Sussex, Phillimore.

THEOTOKIS, G., (2010), The campaigns of the Norman dukes of southern Italy against Byzantium, in the years between 1071 and $1108 \mathrm{AD}, \mathrm{PhD}$ thesis, University of Glasgow.

VASILIEV, A. A., (1937), "The Opening Stages of the Anglo Saxon Immigration to Byzantium in the Eleventh Century," Seminarium Kondakovianum 9, 39-70. 